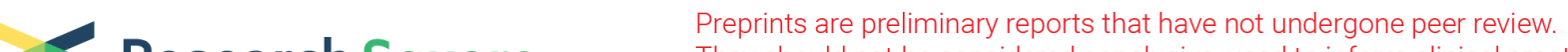 \\ They should not be considered conclusive, used to inform clinical practice, or referenced by the media as validated information.
}

\section{An Integrated Inclusion Health Service for Homeless Adults in Dublin: An Observational, Descriptive Study}

Rikke Siersbaek

University of Dublin Trinity College https://orcid.org/0000-0003-3223-1420

Ann-Marie Lawlee

St. James's Hospital

Joanne Dowds

St. James's Hospital

Aoife Molamphy

St. James's Hospital

Niamh O’Rourke

St. James's Hospital

Una Kennedy

St. James's Hospital

Una Geary

St. James's Hospital

\section{Adrian Moughty}

Mater Misericordiae University Hospital

Jess Sears

Depaul Ireland

Vicky Sandys

St. James's Hospital

Lilly Macken

St. James's Hospital

Ann-Marie Sweeney

St. James's Hospital

Claire Rooney

St. James's Hospital

Clíona Ní Cheallaigh ( $\nabla$ nicheacm@tcd.ie )

https://orcid.org/0000-0002-0842-425X 
Keywords: Homeless Persons, Secondary Care, Quality Improvement, Pilot Projects, Observational studies

Posted Date: January 21st, 2020

DOI: https://doi.org/10.21203/rs.2.21411/v1

License: (c) (1) This work is licensed under a Creative Commons Attribution 4.0 International License. Read Full License 


\section{Abstract}

Background: The pilot Inclusion Health Service was a multi-component intervention designed to improve outcomes for adults experiencing homelessness accessing hospital care. The objectives of this report are to describe the development and evaluation of the Inclusion Health Service.

Method: Observational study reporting on a multi-component intervention including comprehensive assessment and case management of homeless adult inpatients, case management advice to emergency department- and community-based health, and social care providers and education sessions for hospital and community-based staff.

Results: The Inclusion Health Service assessed and developed a comprehensive discharge plan for 262 patients admitted to the hospital. 51 weekly interagency case management meetings took place during the one-year pilot. Additional interventions included education sessions for hospital and communitybased health and social care providers; case management advice to ED and community-based health providers and provision of clothes and personal hygiene items to homeless inpatients. During the intervention, declines in the rate of ED presentations and admissions for homeless adults, compared with the prior year, were observed in the participating hospital. Lengths of stay remained the same.

Conclusion: An Inclusion Health assessment and integrated discharge plan are feasible and acceptable and may have reduced the need for unscheduled healthcare.

\section{Background}

\section{What is homelessness?}

People experiencing homelessness encounter high levels of social exclusion. There are a variety of definitions of homelessness (1) most of which include the full spectrum from sleeping rough (i.e. those sleeping in the open air); living in emergency accommodation such as a hostel, night shelter or B\&B accommodation; and living with family and friends; or in a squat. Homelessness may be short-term and crisis-related, intermittent or chronic (lasting more than one year) (2).

Homelessness is caused by a complex interaction between structural, societal and individual factors. Individual factors which increase vulnerability to becoming or remaining homeless include poverty, adverse childhood experiences, psychiatric disease and addiction to drugs and alcohol. Family conflict and having been in the care of the state are also associated with an increased risk of experiencing homelessness (1). The prevalence of having experienced childhood abuse is strikingly high in this population. Three-quarters of women experiencing homelessness in Canada reported at least one form of abuse, with more than half reporting a history of sexual abuse $(3,4)$. Ongoing victimisation, including physical and sexual assaults, are also common in adults experiencing homelessness. Structural factors that increase the risk of homelessness on a societal level include the absence of low-cost housing, lack of employment opportunities for low-skilled workers, and absence of governmental income support (1). 
Homelessness has become a national crisis in Ireland, with the numbers of people (both single adults and families) experiencing in Ireland having risen by $25 \%$ in the last year alone and tripled in the past four years (5).

\section{Homelessness and health}

Long-term homelessness is characterised by 'tri-morbidity' - the combination of physical and mental illhealth and substance use disorders. As a result, homelessness is associated with dramatic health inequities and poor health outcomes, including earlier onset of chronic disease, multi-morbidity and other usually geriatric syndromes as well as a reduced life expectancy (1).

Homelessness creates barriers to accessing scheduled healthcare and increases the need for unscheduled emergency healthcare. In previous research, we have demonstrated a 20 -fold increase in the use of unscheduled hospital care by adults experiencing homeless in the same Dublin catchment area as the current study. Individuals experiencing homelessness account for $0.4 \%$ of the catchment population but represent over 6\% of Emergency Department (ED) attendances and 7\% of inpatient admissions (6).

\section{Homeless morbidity in Dublin}

A comprehensive survey of the health status of individuals experiencing homelessness in Dublin in 2015 found that $89 \%$ of all study participants had a diagnosed physical or mental health condition(7). By contrast, in the Irish population as a whole, $27.1 \%$ of men and $26.9 \%$ of women have a chronic illness(8). $58.4 \%$ of homeless adults had at least one mental health diagnosis and $69.2 \%$ reported at least one chronic physical health diagnosis with the most commonly diagnosed disorders being peptic or stomach conditions, asthma, high blood pressure, respiratory disease and liver disease. $30.6 \%$ had a bloodborne virus (7).

\section{Inclusion Health}

'Inclusion Health' is an emerging approach which aims to address the extreme health inequities associated with social exclusion. Inclusion Health recognises the increased need for healthcare in socially excluded people and the need for integration between health and social services to provide person-centred, coordinated care. Recent years have seen the development of GP-led specialist hospitalbased homeless health ('Pathway') teams in the UK, with reported benefits in discharge accommodation and patient experience, but not in re-presentations or length of stay $(9,10)$. Many socially excluded people also fall into the patient population described in models of complex care for "high cost, high need" patients $(11-13)$.

\section{Methods}

\section{Study setting}

St James's Hospital is a large university teaching hospital serving adults resident in the Dublin south inner city. Patient data are collected on an electronic patient record (EPR) within the hospital and is also collected in the national hospital in-patient enquiry (HIPE) system, a computerised health information 
system designed to capture demographic, administrative and clinical data on all inpatient discharges from publicly funded acute hospitals in Ireland. Diagnoses recorded on the HIPE system are determined by trained coders on examination of patient records.

We carried out an observational cross-sectional study using data on all ED visits and all unscheduled admissions in St James's Hospital during the year prior to the intervention (August 2015 to July 2016), and during the intervention, (August 2016 to July 2017).

\section{Patient and Public Involvement}

Patient representatives were involved in the design and implementation of the Inclusion Health Service. Patient representatives were not involved in the preparation of the manuscript.

\section{The Intervention}

The intervention (Table 1) is described as per Möhler et al (12). The project team consisted of two of the authors (CNC and $\mathrm{AL}$ ), an acute medical physician and a senior nurse. The project team was advised on an ongoing basis by key figures within the hospital from the social work department, other allied health professionals, emergency department, HIV service, security service as well as community-based health and social care providers and service users. The project team was supported by a quality improvement team comprising of individuals from multiple disciplines with an interest in Inclusion Health (Table 2).

Table 1: Components of the intervention 
Intervention

Description

Comprehensive assessment of homeless inpatients
The comprehensive assessment is a multidimensional interdisciplinary diagnostic process used to determine the medical, psychological, social and functional capabilities of a homeless person to develop a coordinated and integrated plan for treatment and long-term follow-up

Case

management

of frequent

and/or

complex

presenters to

ED
The ED team referred frequent and/or complex attenders to the project team for development of a collaborative case management plan.

\section{Case} management of complex cases in community

Weekly interagency case management meeting

\section{Community-based health and social care} providers were supported in the development of a collaborative case management plan by the project team

\section{Basis of rationale}

Comprehensive assessment has been shown to be of benefit in older adults (14), and homeless adults have been reported to have multimorbidity and functional characteristics of older adults (15)

Case-management (including addressing housing needs) has been shown to reduce ED attendance and inpatient stay in homeless adults with chronic medical illnesses (16)
A weekly meeting was convened by the project team (participating agencies shown in Table 3)
Interagency cooperation and collaboration is frequently used in the management of homeless adults with complex needs and has been shown to be beneficial (17-19)
Structured education sessions for communitybased providers

Structured education sessions for hospital staff

Drop-in HIV/Hepatitis C and Memory clinics
Education sessions were organized to facilitate knowledge exchange between community-based providers and hospital specialists (topics covered shown in Table 4)

Education sessions for groups of hospital staff were held to improve knowledge, skills and attitudes on health equity and traumainformed care (groups shown in Table 5)
Education of community based providers has been shown to increase access of underserved groups to treatment of chronic conditions (20)

A trauma-informed approach has emerged as a successful approach to treating people with a high prevalence of psychological trauma $(21,22)$

People who are experiencing homelessness frequently find attending scheduled outpatient appointments challenging, and drop-in clinics have been shown to be useful in this setting $(23,24)$

Internal Quality Improvement Group
A weekly drop-in HIV/Hepatitis C clinic was established alongside an existing HIV/HCV clinic. Patients could also be referred by community health and social care providers for cognitive assessment
The clinical microsystem approach provides a framework to assess and evaluate the structure, process, and outcomes of care (25) 


\begin{tabular}{|lll|}
\hline Intervention & Description & Basis of rationale \\
\hline $\begin{array}{l}\text { Comfort packs } \\
\text { for homeless } \\
\text { patients }\end{array}$ & $\begin{array}{l}\text { Comfort packs (consisting of shampoo, } \\
\text { deodorant, toothbrush, toothpaste, underwear } \\
\text { and clothes) were given where needed }\end{array}$ & $\begin{array}{l}\text { Provision of clothes and } \\
\text { toiletries as part of a } \\
\text { multicomponent intervention } \\
\text { has been shown to reduce } \\
\text { homeless adults need for acute } \\
\text { unscheduled care (26) }\end{array}$ \\
\hline $\begin{array}{l}\text { Media } \\
\text { campaign }\end{array}$ & Radio, national and international press, Twitter & $\begin{array}{l}\text { Media awareness campaigns } \\
\text { can be used to advance public } \\
\text { policy on health equity (27) }\end{array}$ \\
\hline
\end{tabular}

Table 2: Members of Quality Improvement team

\begin{tabular}{|l|}
\hline Role in hospital \\
\hline - Physiotherapist \\
- Occupational therapist \\
- Ward administrator \\
- Hospital Foundation officer \\
- Financial officer \\
- Consultant physician \\
- Clinical nurse manager \\
- Senior Social Worker \\
\hline
\end{tabular}

The project team were referred any adult experiencing homelessness presenting to the hospital by hospital or external health or social care staff. The project team carried out a comprehensive evaluation comprising of assessment of chronic medical conditions, mobility, cognition, housing, addiction, and mental health. The project team created and coordinated a multidisciplinary interagency discharge plan for all patients seen. This included, as needed, advocating on behalf of the patient with housing providers and liaising with community-based medical and nursing staff, community-based social care staff, opiate substitution providers and other state and voluntary service providers. The project team also provided advice to community-based health and social care staff and drop-in access to outpatient HIV care. Case management, advocacy and case-based education was delivered through a weekly interagency case management meeting (participants described in Table 3). Education was also provided through educational sessions for community-based staff (topics described in Table 4) and for hospital staff on the effect of social exclusion and psychological trauma on health and behavior (staff groups described in Table 5).

Table 3: Participant agencies in weekly interagency meeting 


\begin{tabular}{|lll|}
\hline Agency & Remit & Participants \\
\hline De Paul Ireland & Homeless accommodation provider & $\begin{array}{l}\text { Clinical nurse manager, hostel } \\
\text { managers, project workers }\end{array}$ \\
\hline $\begin{array}{l}\text { Focus } \\
\text { Ireland/Housing } \\
\text { First }\end{array}$ & Outreach team & Project workers, mental health nurse \\
\hline $\begin{array}{l}\text { Merchants Quay } \\
\text { Ireland }\end{array}$ & $\begin{array}{l}\text { Addiction day service for homeless } \\
\text { adults }\end{array}$ & $\begin{array}{l}\text { Nurses, mental health nurses, project } \\
\text { Workers }\end{array}$ \\
\hline $\begin{array}{l}\text { Dublin Simon } \\
\text { Outreach }\end{array}$ & Outreach team & Project workers \\
\hline $\begin{array}{l}\text { Dublin Simon } \\
\text { Detox, Respite }\end{array}$ & Residential detox and respite service & Nurse managers, project workers \\
$\begin{array}{l}\text { Safetynet Primary } \\
\text { Care }\end{array}$ & $\begin{array}{l}\text { Inreach and outreach primary care } \\
\text { for homeless adults }\end{array}$ & $\begin{array}{l}\text { Nurses, general practitioners, project } \\
\text { workers }\end{array}$ \\
\hline $\begin{array}{l}\text { Crosscare } \\
\text { Peter McVerry }\end{array}$ & Homeless accommodation provider & Hostel managers, project workers \\
\hline Trust & Homeless accommodation provider & Hostel managers, project workers \\
\hline
\end{tabular}

Table 4: Topics covered in education sessions

\section{Topic}

- Epilepsy

- Hepatitis C

- The role of Physiotherapy/Occupational Therapy in assessing and supporting the physical and cognitive function of homeless adults

- Venous thromboembolism

Table 5: Hospital education session target groups and fora 


\begin{tabular}{|ll|}
\hline Group & Forum where presentation given \\
\hline $\begin{array}{l}\text { Consultants, junior doctors, hospital managers, allied health } \\
\text { professionals }\end{array}$ & Hospital Grand Rounds \\
\hline Clinical nurse managers & $\begin{array}{l}\text { Nurse manager educational } \\
\text { meeting }\end{array}$ \\
\hline Junior doctors & $\begin{array}{l}\text { Teaching session for registrars and } \\
\text { SHOs }\end{array}$ \\
\hline Social Work & Departmental education session \\
\hline Care Attendants & On ward pop-up sessions \\
\hline ED consultants & City-wide educational meeting \\
\hline Occupational therapists & Departmental meeting \\
\hline
\end{tabular}

\section{Data extraction}

All ED attendances and unscheduled inpatient stays between the 1 August 2015 and 31st July 2016 December 2015 (inclusive) were extracted from hospital databases. Individuals were identified by a unique identifier (medical record number). Length of stay (LOS) was extracted from the hospital patient record. Age was defined as the age of the patient on the date of discharge from hospital.

The unique identifier of each patient seen by the Inclusion Health team was collected. Clinicians extracted data from the patient electronic record including age, gender, type of accommodation prior to admission and diagnoses.

\section{Operational definition of homelessness}

Homeless individuals were defined as those with recorded addresses of no fixed abode (NFA) or any emergency accommodation (homeless hostels). Homeless addresses were extracted from the patient record as previously described (6).

\section{Operational definition of housed and homeless population of catchment area}

The catchment population of the hospital was obtained from previous publications(28). The homeless population of Dublin was taken from data collected by the Dublin Regional Homeless Executive(6).

\section{Staff Survey}

A questionnaire was developed with open and closed questions enquiring into staff knowledge and views of the Inclusion Health Service. The questionnaire was circulated to all hospital staff - an electronic version via the hospital intranet and email and paper copies for manual return. All survey responses were 
anonymous. Data was exported from the electronic survey into Excel. Themes were formed from responses to open ended questions.

\section{Data analysis}

Data were analysed using SPSS.

\section{Ethical approval}

See below.

\section{Results}

262 individuals were assessed by the Inclusion Health team between August 2016 and July 2017 (Table 6). These individuals generated 369 unscheduled inpatient admissions during the intervention period. The median length of stay was seven days but the length varied greatly as described in Table 7.59 (21\%) individuals had more than one unscheduled admission during the intervention period (Table 8).

Table 6

Demographics

\begin{tabular}{|ll|}
\hline & Median (range) \\
\hline Total & 262 \\
Age & $42(19-89)$ \\
\hline Gender & $188(71.8 \%)$ male \\
\hline
\end{tabular}

Table 7

Characteristics of inpatient admissions

\begin{tabular}{|ll|}
\hline & Median (range) \\
\hline Length of stay & $7(0-165)$ \\
\hline Readmissions & $107 / 369(29 \%)$ \\
\hline
\end{tabular}


Table 8

Number of admissions per individual

\begin{tabular}{|ll|}
\hline No of admissions per individual & Individuals $(\mathbf{n = 2 6 2 )}$ \\
\hline 1 & $207(79 \%)$ \\
\hline 2 & $31(12 \%)$ \\
\hline 3 & $10(4 \%)$ \\
$>4$ & $9(4 \%)$ \\
\hline
\end{tabular}

$50.7 \%$ of admissions were in individuals rough sleeping or in emergency accommodation prior to admission (Table 9).

Table 9

Type of accommodation used prior to hospital admission ( $\mathrm{n}$ of admissions $=369$ )

\begin{tabular}{|ll|}
\hline Type of accommodation & Number of admissions (\% of total admissions) \\
\hline Rough sleeping & $71(19 \%)$ \\
\hline Sofa surfing & $11(3 \%)$ \\
\hline Emergency accommodation & $98(27 \%)$ \\
\hline Short-term supported accommodation & $89(24 \%)$ \\
\hline Long-term supported accommodation & $42(11 \%)$ \\
\hline Housing First tenancy & $3(1 \%)$ \\
\hline Unknown & $55(9 \%)$ \\
\hline
\end{tabular}

The most common primary diagnoses were lower respiratory tract infections (LRTIs) and skin and soft tissue infections (SSTIs) (Table 10). The most common co-morbidities were alcohol and drug dependence and hepatitis C (Table 11). 
Table 10

Primary diagnosis

\begin{tabular}{|ll|}
\hline Diagnosis & $\begin{array}{l}\text { Number of admissions (\% of admissions, } \mathbf{n}= \\
\mathbf{3 6 9}\end{array}$ \\
\hline LRTI & $50(14 \%)$ \\
\hline SSTI & $46(13 \%)$ \\
\hline $\begin{array}{l}\text { Chronizure } \\
\text { (COPD)/asthma }\end{array}$ & $29(8 \%)$ \\
\hline Venous thromboembolic disease & $20(5 \%)$ \\
\hline Collapse & $20(5 \%)$ \\
\hline Decompensated chronic liver disease & $17(5 \%)$ \\
\hline Alcohol withdrawal & $16(4 \%)$ \\
\hline Overdose & $13(4 \%)$ \\
\hline Fracture & $13(4 \%)$ \\
\hline Cancer & $11(3 \%)$ \\
\hline Other & $9(3 \%)$ \\
\hline
\end{tabular}


Table 11

Co-morbidities

\begin{tabular}{|lll|}
\hline Co-morbidity & Number of individuals & \% of individuals \\
\hline Injecting drug use & 130 & 50 \\
\hline Hepatitis C (antibody positive) & 118 & 45 \\
\hline Alcohol dependence syndrome & 51 & 19 \\
\hline Seizure disorder & 44 & 17 \\
\hline Depression/anxiety & 38 & 15 \\
\hline Cirrhosis & 34 & 13 \\
\hline COPD & 23 & 9 \\
\hline HIV & 23 & 9 \\
\hline Gastritis/peptic ulcer disease & 21 & 8 \\
\hline Asthma & 15 & 6 \\
\hline Diabetes mellitus (Type 1 and Type 2) & 15 & 6 \\
\hline Venous thromboembolic disease & 15 & 6 \\
\hline Pancreatitis & 15 & 6 \\
\hline Schizophrenia/bipolar disorder & 13 & 5 \\
\hline
\end{tabular}

The per capita ED presentation rate and unscheduled admission rate for housed and homeless individuals were calculated for the year prior to the intervention and the study period (Table 12). The catchment population of the hospitals was obtained as previously described $(7,9)$. Per capita ED presentation and unscheduled admission rates were lower during the intervention period than the preintervention period ( $p<0.01$, Fisher's exact test). There was no statistically significant difference in length of stay for homeless individuals between the pre-intervention and intervention period (Mann-Whitney test). Data on ED presentations from the other acute adult hospital in the inner city was for the year prior to the intervention and the study period was also obtained and analysed similarly. 
Table 12

ED and unscheduled admissions

\begin{tabular}{|lllll|}
\hline & \multicolumn{2}{l}{ Aug 2015 - July 2016 } & \multicolumn{2}{l|}{ Aug 2016 - July 2017 } \\
\hline & Housed & Homeless & Housed & Homeless \\
\hline Adults in catchment area & 270,000 & 3,224 & 270,000 & 3,919 \\
\hline ED presentations & 47,808 & 3,211 & 48,437 & 2,975 \\
\hline ED presentations per capita & 0.18 & 1.00 & 0.18 & 0.76 \\
\hline ED presentations to other hospital & & 3,483 & & 3,764 \\
\hline $\begin{array}{l}\text { ED presentations to other hospital per } \\
\text { capita }\end{array}$ & & 1.08 & & 0.96 \\
\hline Medical admissions & 22,255 & 394 & 22,835 & 369 \\
\hline Medical admissions per capita & 0.08 & 0.12 & 0.08 & 0.09 \\
\hline $\begin{array}{l}\text { Mean LOS } \\
\text { (SD) }\end{array}$ & $\begin{array}{l}8.63 \\
(16.647)\end{array}$ & $\begin{array}{l}8.94 \\
(17.731)\end{array}$ & $\begin{array}{l}8.25 \\
(15.213)\end{array}$ & $\begin{array}{l}9.01 \\
\text { (18.53) }\end{array}$ \\
\hline
\end{tabular}

128 staff members of a total of 4000 staff employed by the hospital responded to the questionnaire (Table 13). Respondents are described in Table 13. 117/128 respondents (92\%) reported having encountered homeless patients during their work. 89/128 (70\%) reported having encountered the Inclusion Health Service while providing care to homeless patients. $115(94 \%)$ reported a benefit of the service for patients - benefits reported included provision of clean clothing, improved access to accommodation on discharge and improved communication with external services. Respondents commented that the service built rapport with homeless patients, brought out the patients' best qualities and improved patient dignity. Staff also reported that the service led to fewer admissions and readmissions. 112/128 reported that the service benefited hospital staff, with reported benefits including more cohesive services, more expertise in field, and improved patient attendance at outpatients and adherence to treatment. 
Table 13

Staff survey respondents

\begin{tabular}{|ll|}
\hline Role & Number (percentage of total) \\
\hline Medical & $51(40 \%)$ \\
\hline Nursing & $31(24 \%)$ \\
\hline Health and social care professionals & $34(27 \%)$ \\
\hline Health care attendants & $3(2.3 \%)$ \\
\hline Other & $9(7 \%)$ \\
\hline
\end{tabular}

\section{Discussion}

Dublin, similar to many other cities, has seen a dramatic increase in the number of people experiencing homelessness in recent years (10). Homeless people have complex health needs and require coordination of health and social care (29). People who experience homelessness access secondary care more frequently than housed populations, and increases in homelessness place added burden on acute hospital services (6).

In this paper, we describe a multicomponent complex intervention to improve care for patients experiencing homelessness. The service addresses the need for a high degree of coordination of care between secondary and primary health care providers and social care providers. The service provided housing advocacy and liaised with community-based medical and nursing staff, community-based social care staff, opiate substitution providers and other state and voluntary service providers. Project staff also educated hospital staff on homelessness, social exclusion and trauma-informed practice and educated community-based providers on the management of common chronic conditions.

Staff feedback on the service was positive, with the majority of staff reporting benefits to homeless patients and staff. In addition, there was a reduction in the usage of unscheduled hospital care by adults experiencing homelessness during the duration of the project. Of note, this was an observational study without formal controls and there is a likelihood that interventions (e.g. educational, case management) in the pilot hospital affected other hospitals attended by the same homeless individuals or homeless individuals attending services involved with the pilot programme. External factors such as changes in provision of accommodation and keyworking services may have played a role, however the Mater Misericordiae University Hospital, another Dublin inner city hospital with a similar rate of homeless presentations, did not experience a reduction in homeless ED presentations as large as that observed in St. James's.

The observations reported here are likely to be relevant in other resource-rich cities with high homeless populations. The tri-morbidity of physical and mental ill-health and addiction seen in homeless adults in Dublin is similar to that seen in other large cities in resource-rich countries (1). This study provides further 
evidence of the benefit of integrated, collaborative multicomponent interventions for high-cost, high-need patients such as homeless adults who receive better care and to hospitals and the health system as a whole through fewer attendances and admissions. Policy makers and healthcare administrators should consider investing in interventions that provide intensive and coordinated care across health, housing and social care when a patient experiencing homelessness enters secondary care to free up hospital beds and other resources downstream.

\section{Conclusion}

We describe a multi-component Inclusion Health intervention for adults experiencing homelessness accessing hospital services which was feasible, acceptable and was associated with reduced use of acute unscheduled care. Future work will expand upon this research to evaluate the effectiveness of this kind of service against usual care and to determine the cost-effectiveness. A similar approach may be useful in other settings with socially excluded people experiencing high levels of multimorbidity.

\section{Abbreviations}

ED

Emergency Department

EPR

electronic patient record

HIPE

national hospital in-patient enquiry

LOS

length of stay (LOS

HIV

Human Immunodeficiency Virus

LRTI

lower respiratory tract infection

SSTI

skin and soft tissue infection

COPD

chronic obstructive pulmonary disease

SD

Standard deviation

\section{Declarations}

Competing interests 
All authors have completed the Unified Competing Interest form and declare: support from the Health Research Board, Ireland (HRB) and the Health Services Executive, Ireland (HSE) for the submitted work; no financial relationships with any organisations that might have an interest in the submitted work in the previous 3 years, no other relationships or activities that could appear to have influenced the submitted work.

\section{Authors contributiom}

RS: literature search, data interpretation, writing of manuscript; $A M L, J D, A M, N O^{\prime} R, U K, U G, J S, A M$ : intervention design, study design, data interpretation and writing of manuscript: VS, LM, CR, AS: data collection, editing of manuscript CNC: literature search, intervention design, study design, data collection, data analysis, data interpretation and writing of manuscript.

\section{Funding}

This work was supported by the Health Research Board (APA 2018_029) and (SPHeRE/2013/1)

\section{Ethics approval and consent to participate}

The study was approved by the Joint Hospitals Research Ethics Committee of St James's Hospital and Tallaght University Hospital (REC Reference: 2017-05) and by the Mater Misericordiae University Hospital Research Ethics Committee (1/378/1627 TMR). This study was based on analysis of routinely collected administrative data and consent was not sought for data processing.

\section{Consent for publication}

Not applicable

Availability of data and materials

De-identified data may be obtained via correspondence

Acknowledgements

Donnacha Creagh, Fiona O’Reilly, Austin O'Carroll

\section{References}

1. Fazel S, Geddes JR, Kushel M. The health of homeless people in high-income countries: Descriptive epidemiology, health consequences, and clinical and policy recommendations. Lancet [Internet]. 2014;384(9953):1529-40. Available from: http://dx.doi.org/10.1016/S0140-6736(14)61132-6

2. Culhane DP, Kuhn R. Applying cluster analysis to test a typology of homelessness by ... Am J Community Psychol. 1998;26(2):207-32. 
3. Torchalla I, Linden IA, Strehlau V, Neilson EK, Krausz M. "Like a lots happened with my whole childhood": violence, trauma, and addiction in pregnant and postpartum women from Vancouver's Downtown Eastside. Harm Reduct J. 2015;12:1.

4. Anderson I, Christain J. Causes of Homelessnes in the UK: A Dynamic Analysis". J Community Appl Soc Psychol. 2003;13:105-18.

5. Focus Ireland. Latest Figures on Homelessness in Ireland [Internet]. 2019. Available from: https://www.focusireland.ie/resource-hub/latest-figures-homelessness-ireland/

6. Ní Cheallaigh C, Cullivan S, Sears J, Lawlee AM, Browne J, Kieran J, et al. Usage of unscheduled hospital care by homeless individuals in Dublin, Ireland: a cross-sectional study. BMJ Open [Internet]. 2017 Dec 1 [cited 2018 May 14];7(11):e016420. Available from:

http://www.ncbi.nlm.nih.gov/pubmed/29196477

7. 0 'Reilly F, Barror S, Hannigan A, Scriver S, Ruane L, Macfarlane A, et al. Homelessness: An unhealthy state. Health status, risk behaviours and service utilisation among homeless people in two irish cities. The Partnership for Health Equity. 2015.

8. Governement of Ireland. Health in ireland. Department of Health. 2018.

9. Hewett N, Halligan A, Boyce T. A general practitioner and nurse led approach to improving hospital care for homeless people. BMJ. 2012;345(7877):1-6.

10. Hewett N, Buchman P, Musariri J, Sargeant C, Johnson P, Abeysekera K, et al. Randomised controlled trial of GP-led in-hospital management of homeless people ('Pathway'). Clin Med J R Coll Physicians London. 2016;16(3):223-9.

11. Blumenthal D, Chernof B, Fulmer T, Lumpkin J, Selberg J. Caring for High-Need, High-Cost Patients An Urgent Priority. N Engl J Med. 2016;375(10):909-11.

12. Berry LL, Rock BL, Houskamp BS, Brueggeman J, Tucker L. Care coordination for patients with complex health profiles in inpatient and outpatient settings. Mayo Clin Proc [Internet]. 2013;88(2):184-94. Available from: http://dx.doi.org/10.1016/j.mayocp.2012.10.016

13. Goodell S, Bodenheimer T, Berry-Millet R. <title>Four-wave mixing of the fundamental, Stokes, and anti-Stokes waves in a single-mode birefringent fiber: influence of initial conditions on energy exchange among waves and optical switching</title> [Internet]. Vol. 19, Care management of patients with complex health care needs. Princeton, NJ; 2009. Available from: https://www.rwjf.org/en/library/research/2009/12/care-management-of-patients-with-complexhealth-care-needs.html

14. Ellis G, Whitehead MA, Robinson D, O’Neill D, Langhorne P. Comprehensive geriatric assessment for older adults admitted to hospital: Meta-analysis of randomised controlled trials. BMJ. 2011;343(7832):1034.

15. Brown RT, Hemati K, Riley ED, Lee CT, Ponath C, Tieu L, et al. Geriatric Conditions in a PopulationBased Sample of Older Homeless Adults. Gerontologist. 2017;57(4):757-66.

16. Sadowski LS, Kee RA, Vanderweele TJ, Buchanan D. Effect of a housing and case management program on emergency department visitsand hospitalizations among chronically III homeless adults 
a randomized trial. JAMA - J Am Med Assoc. 2009;301(17):1771-8.

17. Culhane DP, Byrne T. Ending Chronic Homelessness: Cost - Effective Opportunities for Interagency Collaboration. Penn Sch Soc Policy Pract Work Pap [Internet]. 2010;1-30. Available from: https://repository.upenn.edu/cgi/viewcontent.cgi?article=1151\&context=spp_papers

18. Grace M, Coventry L, Batterham D. The role of interagency collaboration in "joined-up" case management. J Interprof Care. 2012;26(2):141-9.

19. Rosenheck RA, Resnick SG, Morrissey JP. Closing service system gaps for homeless clients with a dual diagnosis: Integrated teams and interagency cooperation. J Ment Health Policy Econ. 2003;6(2):77-87.

20. Arora S, Thornton K, Komaromy M, Kalishman S, Katzman J, Duhigg D. Demonopolizing medical knowledge. Acad Med. 2014;89(1):30-2.

21. Elliott DE, Bjelajac P, Fallot RD, Markoff LS, Reed BG. Trauma-informed or trauma-denied: Principles and implementation of trauma-informed services for women. J Community Psychol. 2005;33(4):461-77.

22. Sweeney A, Clement S, Filson B, Kennedy A. Trauma-informed mental healthcare in the UK: What is it and how can we further its development? Ment Heal Rev J. 2016;21(3):174-92.

23. Crane M, Warnes AM. Primary health care services for single homeless people: Defects and opportunities. Fam Pract. 2001;18(3):272-6.

24. Keogh C, O 'brien KK, Hoban A, O 'carroll A, Fahey T, O'Brien KK, et al. Health and use of health services of people who are homeless and at risk of homelessness who receive free primary health care in Dublin 58. BMC Health Serv Res [Internet]. 2015 [cited 2018 May 14];15(1):1-8. Available from: http://creativecommons.org/licenses/by-nc-sa/1.0/

25. Mohr JJ, Batalden PB. Improving safety on the front lines: The role of clinical microsystems. Qual Saf Heal Care. 2002;11(1):45-50.

26. O'Toole TP, Johnson EE, Aiello R, Kane V, Pape L. Tailoring Care to vulnerable populations by incorporating social determinants of health: The veterans health administration's "homeless patient aligned care team" program. Prev Chronic Dis. 2016;13(3):1-12.

27. Wallack L. Media Advocacy: A Strategy for Empowering People and Communities Author ( s ): Lawrence Wallack Source: Journal of Public Health Policy , Vol . 15 , No . 4 (Winter , 1994 ), pp . 420436 Published by: Palgrave Macmillan Journals Stable URL: http://ww. 2017;15(4):420-36.

28. Conway R, Byrne D, O’Riordan D, Cournane S, Coveney S, Silke B. Deprivation index and dependency ratio are key determinants of emergency medical admission rates. Eur J Intern Med [Internet]. 2015;26(9):709-13. Available from: http://dx.doi.org/10.1016/j.ejim.2015.09.010

29. Luchenski S, Maguire N, Aldridge RW, Hayward A, Story A, Perri P, et al. What works in inclusion health: overview of effective interventions for marginalised and excluded populations. Lancet (London, England) [Internet]. 2018;391(10117):266-80. Available from: http://ovidsp.ovid.com/ovidweb.cgi?T=JS\&PAGE=reference\&D=med13\&NEWS=N\&AN=29137868 